\title{
Nursery Science and Conventions
}

\author{
Lu DY1*, Chen $\mathrm{YZ}^{2}$ and Lu DF \\ ${ }^{1}$ School of Life Sciences, Shanghai University, China \\ ${ }^{2}$ The Second Hospital of Neijiang District, China
}

*Corresponding author: Da Yong Lu, School of Life Sciences, Shanghai University, Shanghai200444, PRC, China, Email: ludayong@shu.edu.cn

\section{Research Article}

Volume 3 Issue 5

Received Date: September 07, 2019

Published Date: September 27, 2019

DOI: $10.23880 /$ nhij- 16000203

\section{Abstract}

A great proportion of medical science needs high-quality nursery and technical assistance. Nursery science is pervasive across all medical disciplines. Nonetheless, the distribution and education of nursery science is under-performed worldwide. The quality and diversity of nursing services and technical support can be improved from medical science advances, propaganda, economic optimizing, clinical validation and updates. Patient's nursery service plays key roles in modern hospitals. To promote these kinds of medical and technical work, new nursery systems must be implemented for quality promotion and disease treatments. Patient's nursery service plays key roles in modern hospitals. To promote these kinds of medical and technical work, new nursery systems must be implemented for quality promotion and disease treatments. This article addresses medical promotion of a number of nursery sciences and effective projects-including college education, talent recruits, personal training, medical knowledge advances, distribution, convention evolution, clinical requirements, technical innovation and most important (financial supports and status improvements).

Keywords: Healthcare; Nursing; Medical service; Modern technology; Education; Personalized medicine, Obesity; Psycho-analysis

\section{Abbreviations: BMI: Body Mass Index.}

\section{Introduction}

\section{Historic Overview}

Today, medical science developments continue to progress. Their treatment processes are not defined in operation-room (surgery) and drug utility (chemical, herbal or bioagents) [1]. Getting better in the bedside and nursery demand new generation of medical services (surgery, drug, nutrition and instruments) and nursery service (physical or spiritual assistance) [1-4]. Healthcare improvements remain to greatly improve with and without huge financial supports [5-13]. A great deal of chronic or dying patient in a general hospital can be better served by program of both doctors and nursing [14-17]. Rapid progress of nursery service receives health-care reward and patient recognition.

\section{Current Progress}

Medical care and nursing advances help patient's recovery and disease controls in the clinic. The medical significance of the quality improvements of medical healthcare and nursing activity is notable [1-10]. Nursery science and activity continue to progress in a rapid manner [10-12]. Many medical knowledge advances will certainly translate into new form in the bedside. Following methodology is useful means to teach all nurses. 


\section{Methods}

\section{General Methodology in Different Medical Discipline}

There is no nursery knowledge that can be applied on every medical discipline. However, it suggests that knowledge spread should target different biomedical disciplines as much as possible [16]. (Table 1) and Table 2 show a glimpse of major skills that nurses in every discipline should be familiar with and get acquaintance onto [13-18] (Tables $1 \& 2$ ).

\begin{tabular}{|c|c|}
\hline Disease types & Major targets \\
\hline Infection & Body temperature, isolation, vaccination and drug uses \\
\hline Obstetric & Child, mother, human fertility, fetus observation \\
\hline Mental disorders & Excitement, agitation, cognitive, depression, excite \\
\hline Oncology & Surgery, drugs and emergency \\
\hline Metabolic disease & Obesity, nutrients, drug and life-style \\
\hline Orthopedics & Immobile and osteoporosis \\
\hline Cardiovascular & Blood pressure, electrocardiography and angiography \\
\hline Handicaps & Limb/foot, blind, deaf and speechless \\
\hline Pediatric & Helping-hands for the children \\
\hline Gastro-intestinal & Bleed and digests \\
\hline
\end{tabular}

Table 1: A general picture of nursery services for major diseases.

\begin{tabular}{|c|c|c|}
\hline Major disciplines & Technical catalog & Requirements \\
\hline Surgery and anesthesia & Local or whole-body & Individual conditions \\
\hline Psychiatric & Cognitive, behavior and emotional & Suicidal risk and custody \\
\hline Emergency & Blood, respiratory and life indicates & Testing and support \\
\hline Pharmacology & Efficacy and toxicity monitors & Careful observation \\
\hline Nursery & Different medical disciplines & Physical and spiritual \\
\hline Patient condition & Gender and ages & Emphasize for categories \\
\hline
\end{tabular}

Table 2: Medical service from technical and health-care requirements.

\section{System Establishments}

It is not difficult to see the capability promotion of nurses can improve patient's health care. System developments for nursery should not be neglected in most hospitals. Hospitals provide nursery services according to their capability and interests. Excellent health care services and nurses should be targeted to most patients and proper nurses. As a result, individualized nursing systems should be established in the upcoming decades and more hospitals.

\section{Major parts of nursery education}

- Nursery recruitment (different backgrounds and gender).

- Early training (every details of hospital convention).

- Basic skill familiar (patient feeding and supports).

- Pharmacology (therapeutic outcome observation).

- Drug side-effects (check-out therapeutic toxicity and mistake).

- Assistance for doctor.

Lu DY, et al. Nursery Science and Conventions. Nurs Health Care Int J 2019, 3(5): 000203.
- Diagnosis assistance (blood or urine tests).

- Nutrition knowledge (maintaining the health of patients).

- Communication skills.

- Patient's psychiatric-index and condition (cognitive, behavior and emotions).

\section{Pharmacological Knowledge}

Currently, different personalized medicines are gearing up in more global hospitals [18-24]. Entering into this millennium, technical, drug developments, clinical pharmacology, toxicology and education for nurses increase dramatically. Since the patho-physiological conditions are different from patient to patient. The different patho-physiological conditions, like body mass index (BMI), patient age, size and height, comorbidity, and other complications need different healthcare services and medical disciplines [25-28]. Doctors are often not able to guide all these different services, especially drug toxicology and monitor. Cost balance between doctors' diagnosis/prescription and patients' nursing activity to 
individual patients will be future avenues. Otherwise, nurses will also report some treatment mistakes from doctors to higher regulatory levels and networkincluding drug toxicology and therapeutic failures [29].

\section{Patient Emotion Control}

Patients are often anxiety, agitated, excited or depressed by the agony of disease progress or relieving while treatment outcomes are different from their expectation. Patient's psychiatric condition is often not stable. Careful spiritual supports can change the course of disease recovery [11]. We must keep in mind for this kind of medical services and make it a therapeutic routine.

\section{Diversity of Nursery Work}

A great different functionality in the hospitals is performed by nurses (Table 3). In order to do so, nurses are required to do a lot of different activity and services. They need to have this mindset before they are entered into hospitals and healthcare center.

\begin{tabular}{|c|c|}
\hline Categories & Function \\
\hline Doctor assistance & $\begin{array}{c}\text { Surgery, drug distribution, } \\
\text { communication with family }\end{array}$ \\
\hline Patient assistance & $\begin{array}{c}\text { Drug administration, function } \\
\text { recovery }\end{array}$ \\
\hline Basic diagnosis & $\begin{array}{c}\text { Blood glucose level or other test, } \\
\text { urine test, temperature }\end{array}$ \\
\hline Basic administration & $\begin{array}{c}\text { Hospital function, data record, } \\
\text { room cleaming }\end{array}$ \\
\hline
\end{tabular}

Table 3: Categories of nursery service.

\section{Future Directions}

\section{Joint Efforts}

Therapeutics in the future is no longer a decisionmaking by doctors only [30,31]. Many technical or assistance forces (including patients themselves) will take part of medical practice-including pharmacologists, pathologists, biochemical technologists, nurses, mathematicians and patient's family members. Without the assistance of these experts and family members, clinical doctors will be narrow-minded and difficult to execute best therapeutics for all patients. This modern trend is unavoidable and eventually improving globally.

\section{Targets for Different Disease Categories and Pharmacology}

In summary, different types of nursery play key roles in different clinical trials and circumstances, especially chronic diseases, such as viral infection [32-35], mental diseases [36-39], bone disorders [40-43], metabolic diseases [44-49], cancer metastasis treatments [50-57] and multi-targeted drugs [58]. After all, nursery should be familiar with all these knowledge of medical disciplines and execute their service in good details.

\section{Conclusion}

Patient's nursery service plays key roles in modern hospitals. To promote these kinds of medical and technical work, new nursery systems must be implemented for quality promotion and disease treatments. After all, nursery activities should be more emphasized for all medical disciplines and patient treatments. No matter what kind of efforts we shall do, they are very useful in patient treatment and recovery after all.

\section{References}

1. Lu DY, Lu TR (2019) Herbal medicine in new era. Hospice Palliative Medicine International J 3(4): 125130.

2. Lu DY, Chen YZ, Lu DF, Che JY (2019) Patient's care and nursery in different diseases. Hospice \& Palliative Medicine International Journal 3(1): 28-30.

3. Lu DY, Chen YZ, Lu DF, Che JY (2019) Patient's care and nursery in modern medicine. Nursery Practice Health Care 1(1): 101.

4. Lu DY, Chen YZ, Lu DF (2019) Nursery education, capability and service promotion. Open Access Journal of Nursing 2(2): 1-4.

5. Iqbal U, Humayyn A, Li YC (2019) Healthcare quality improvement and measurement strategies and its challenges ahead. Int J Quality in Health Care 31(1): 1.

6. Iqbal U, Rabrenovic M, Li YC (2019) Healthcare quality challenges in low- and middle-income countries. Int J Qual Health Care 31(3): 165.

7. Lu DY, Che JY, Putta S, Wu HY, Shen Y (2019) How to improve the quality of pharmacotherapy for bone diseases. EC Orthopeadicis., 10 (6): 366-369.

8. Leebov W, Scott G (1996) Service quality improvement. The customer satisfaction strategy for healthcare. J Healthcare Quality 18(4): 35. 


\section{Nursing \& Healthcare International Journal}

9. Lu DY, Chen YZ, Lu DF (2019) Nursery service, quality promotion. Hospice \& Palliative Medicine International J 3(3): 97-98.

10. Lu DY, Chen YZ, Lu DF, Che JY (2019) Nursery service in modern day. Adv Biomedical Engineering Biotechnology 1(3): 1-2.

11. Lu DY (2019) Bone disease recovery strategies, nursery importance. EC Dental Science 18(6): 326327.

12. Ghaffari M (2019) Building a community of learners: Lessons learned. Nursery Practice and Health Care 1(1): 104.

13. (2013) An Old Disease, A New Insights, (Ed), Shamm Ahmad, Springer Science, US.

14. Zimmet PZ, Magliano DJ, Herman WH, Shaw JE (2014) Diabetes; a 21st century challenge. Lancet Diabetes Endocrinol 2(1): 56-64.

15. Grimaccia F, Kanavos P (2014) Cost, outcome, treatment pathways and challenges for diabetes care in Italy. Globalization Health 10: 58.

16. Lu DY (2017) Suicide Risks and Treatments, New Ideas and Future Perspectives. In: Lu DY (Ed), Nova Science Publishers, New York, US.

17. Lu DY (2017) HIV/AIDS Treatments, Fight for a Cure. In: Lu DY (Eds.), Lambert Academic Publishing Germany.

18. Lu DY (2014) Personalized cancer chemotherapy, an effective way for enhancing outcomes in clinics, Woodhead Publishing, Elsevier, UK.

19. Lu DY, Chen XL, Ding J (2006) Individualized cancer chemotherapy integrating drug sensitivity tests, pathological profile analysis and computational coordination-an effective strategy to improve clinical treatment. Medical Hypotheses 66(1): 45-51.

20. Lu DY, Lu TR, Ding J, Xu B, Che JY, et al. (2015) Anticancer drug sensitivity testing, a historical review and future perspectives. Current Drug Therapy 10 (1): 44-55.

21. Lu DY, Lu TR, Xu B, Ding J (2015) Pharmacogenetics of cancer therapy: breakthroughs from beyond? Future Sci OA 1(4): FSO80.

22. Lu DY, Lu TR, Che JY, Yarla NS (2018) Individualized cancer therapy, what is the next generation? EC Cancer 2(6): 286-297.

Lu DY, et al. Nursery Science and Conventions. Nurs Health Care Int J 2019, 3(5): 000203.
23. Lu DY, Xu B, Ding J, Lu TR, Yarla NS, et al. (2018) Cancer Bioinformatics in Cancer Therapy. Adv Proteomics Bioinformatics pp: 1-7.

24. Lu DY, Lu TR, Che JY, Shen Y, Yarla NS, et al. (2018) Individualized cancer therapy, future approaches. Current Pharmacogenomics \& Personalized Medicine. 16(2): 156-163.

25. Lu DY, Che JY, Putta S (2018) Obese study, keep up the momentum. Int J Endocrinology Res 1(1): 1-3.

26. Lu DY, Che JY, Yarla NS, Putta S, Lin LP, et al. (2019) Human obesity, pathological and therapeutic advances. EC Pharmacology \& Toxicology 7 (4): 231238.

27. Lu DY, Che JY, Shen Y (2018) Clinical treatments of osteoporosis, how to target co-morbidities. EC Orthopaedics 9(11): 781-782.

28. Lu DY, Che JY, Shen ZM, Tong LJ, Lin LP, et al. (2019) Osteoporosis treatments for old people. EC Orthopeadicis 10(5): 278-280.

29. Dirik HF, Samur M, Intepeler SS, Hewison A (2018) Nurses' identification and reporting of medication errors. J Clin Nursing 28(5-6): 931-938.

30. Lu DY, Zhu PP, Lu TR, Che JY (2016) The suicidal risks and treatments, seek medications from multidisciplinary. Cent Nerv Syst Agents Med Chem 16(3): 231-239.

31. Lu DY, Zhu PP, Wu HY, Lu Y, Che JY (2017) New modes of suicide/mental disorder diagnostics and therapeutics. In: Lu DY (Eds.), Suicide Risks and Treatments, New Ideas and Future Perspectives. (Chapter 5), Nova Science Publishers, US, pp: 51-62.

32. Lu DY, Wu HY, Yarla NS, Xu B, Ding J, et al. (2018) HAART in HIV/AIDS treatments, future trends. Infect Disord Drug Targets 18(1): 15-22.

33. Lu DY, Wu HY, Ding J, Sastry N, Lu TR (2016) HIV vaccine for prevention and cure, a mission possible. Rev Recent Clini Trials 11(4): 290-296.

34. Lu DY, Lu TR, Wu HY, Yarla NS, Ding J, et al. (2018) HIV/AIDS curable study, new forms of therapeutic trinity. Rec Pat Antiinfect Drug Discov 13(3): 217227.

35. Lu DY, Wu Hy, Yarla NS, Lu TR, Xu B, et al. (2019) Ebola therapeutic study and future trends. Infect Disorder Drug Targets 19(1): 17-29. 


\section{Nursing \& Healthcare International Journal}

36. Serafini G, Salano P, Amore M (2015) Suicidal ideation: a comprehensive overview. Suicidal Ideation: Predictors, Prevalence and Prevention. In: Weaver B (Eds.), (Chapter 1) Nova Science Publishing, US, pp: 1-42.

37. While D, Bickley H, Roscoe A, Windfuhr K, Rahman S, et al. (2012) Implementation of mental health service recommendations in England and Wales and suicide rates, 1997-2006: a cross-sectional and before-andafter observational study. Lancet 379: 1005-1012.

38. Lu DY, Lu TR, Lu Y, Cao S (2017) Introduction for suicide study. Journal Metabolic Syndrome 6(2): 227.

39. Lu DY, Zhu PP, Wu HY, Yarla NS, Xu B, et al. (2018) Human suicide risk and treatment study. Cent Nerv Syst Agents Med Chem 18(3): 206-212.

40. Melton J (1993) Hip fracture: a worldwide problem today and tomorrow. Bone 14: S1-8.

41. Silva DMW (2018) Diagnosis of osteoporosis; bone mineral density, risk factors, or both. EC Orthopaedics 9(7): 500-502.

42. Lu DY, Che JY, Shen Y (2018) Osteoporosis in old women, therapeutic selection. EC Orthopaedics 9(7): 386.

43. Lu DY, Che JY, Shen Y (2018) Clinical treatments of osteoporosis, how to target co-morbidities. EC Orthopaedics 9(11): 781-782.

44. Putta S, Peluso I, Yarla NS, Kilari EK, Bishayee A, et al. (2017) Diabetes mellitus and male aging, pharmacotherapeutics and clinical implications. Curr Pharm Des 23(30): 4475-4483.

45. Lu DY, Che JY, Yarla NS, Zhu H, Lu TR, et al. (2018) Type 2 diabetes study, introduction and perspective. The Open Diabetes J 8: 13-21.

46. Lu DY, Che JY, Yarla NS, Wu HY, Lu TR, et al. (2018) Type 2 diabetes treatment and drug development study. The Open Diabetes J 8: 22-33.

47. Lu DY, Che JY, Lu Y, Yarla NS, Xu B, et al. (2018) An overview of obesity. Metabolomics 8(2): 200.
48. Lu DY, Che JY, Wu HY, Yarla NS, Xu B, et al. (2018) Obesity, risks and managements. Metabolomics 8(1): e156.

49. Lu DY, Che JY, Lu TR, Lu Y, Huang YK, et al. (2018) Pathology and treatments of obesity. Trends in Medicine 8(5): 1-2.

50. Lu DY, Lu TR, Wu HY, Cao S (2013) Cancer Metastasis treatments. Current Drug Therapy 8(1): 24-29.

51. Nieto MA, Huang RY, Jackson RA, Thiery JP (2016) EMT 2016. Cell 166(1): 21-45.

52. Lu DY, Lu TR, Xu B, Qi RX, Sastry NY, et al. (2016) Cancer metastasis, a clinical dilemma for therapeutics. Current Drug Therapy 11(2):163-169.

53. Lu DY, Xu B, Ding J (2004) Antitumor effects of two bisdioxopiperazines against two experimental lung cancer models in vivo. BMC Pharmacology 4: 32.

54. Lu DY, Huang M, Hu CX, Yang WY, Hu CX, et al. (2005) Anti-proliferative effects, cell cycle $\mathrm{G}_{2} / \mathrm{M}$ phase arrest and blocking of chromosome segregation by probimane and MST-16 in human tumor cell lines. BMC Pharmacology 5:11.

55. Lu DY, Chen XL, Ding J (2007) Treatment of solid tumors and metastases by fibrinogen-targeted anticancer drug therapy. Medical Hypotheses 68(1): 188-193.

56. Lu DY, Lu TR (2010) Antimetastatic activities and mechanisms of bisdioxopiperazine compounds. Anticancer Agents Med Chemi 10(7): 564-570.

57. Lambert, AW, Pattabiraman DR, Weinberg RA (2017) Emerging biological principles of metastasis. Cell 168(4): 670-691.

58. Putta S, Yarla NS, Peluso I, Tiwari DK, Reddy GV, et al. (2017) Anthocyanins: Possible role as multitarget therapeutic agents for prevention and therapy of chronic diseases. Current Pharmaceutical Design 23(41): 6321-6346. 